\title{
The 63-year changes in annual streamflow volumes across Europe with a focus on the Mediterranean basin
}

\author{
Daniele Masseroni $^{1}$, Stefania Camici ${ }^{2}$, Alessio Cislaghi ${ }^{1,3}$, Giorgio Vacchiano $^{1,3}$, Christian Massari $^{2}$, and Luca Brocca ${ }^{2}$ \\ ${ }^{1}$ Department of Agricultural and Environmental Sciences, University of Milan, Via Celoria 2, 20133 Milan, Italy \\ ${ }^{2}$ Research Institute for Geo-Hydrological Protection, National Research Council, Via Madonna Alta 126, 06128 Perugia, Italy \\ ${ }^{3}$ Centre of Applied Studies for the Sustainable Management and Protection of Mountain Areas (Ge.S.Di.Mont), \\ University of Milan, Via Morino 8, 25048 Edolo, Brescia, Italy
}

Correspondence: Daniele Masseroni (daniele.masseroni@unimi.it)

Received: 16 January 2020 - Discussion started: 27 January 2020

Revised: 20 September 2021 - Accepted: 3 October 2021 - Published: 25 October 2021

\begin{abstract}
Determining the spatiotemporal variability in the annual streamflow volume plays a relevant role in hydrology with regard to improving and implementing sustainable and resilient policies and practices of water resource management. This study investigates annual streamflow volume trends in a newly assembled, consolidated, and validated data set of daily mean river flow records from more than 3000 stations which cover near-natural basins in more than 40 countries across Europe. Although the data set contains streamflow time series from 1900 to 2013 in some stations, the statistical analyses were carried out by including observations from 1950 to 2013 in order to have a consistent and reliable data set over the continent. Trends were detected by calculating the slope of the Theil-Sen line over the annual anomalies of streamflow volume.

The results show that annual streamflow volume trends have emerged at European scale, with a marked negative tendency in Mediterranean regions, with about $-1 \times$ $10^{3} \mathrm{~m}^{3} /\left(\mathrm{km}^{2} \mathrm{yr}^{-2}\right)$, and a generally positive trend in northern ones, with about $0.5 \times 10^{3} \mathrm{~m}^{3} /\left(\mathrm{km}^{-2} \mathrm{yr}^{-2}\right)$. The annual streamflow volume trend patterns appear to be in agreement with the continental-scale meteorological observations in response to climate change drivers. In the Mediterranean area, the decline of annual streamflow volumes started in 1965, and since the early 1980s, volumes have consistently been lower than the 1950-2013 average.

The spatiotemporal annual streamflow volume patterns observed in this work can help to contextualize short-term trends and regional studies already available in the scientific
\end{abstract}

literature, as well as to provide a valid benchmark for further accurate quantitative analysis of annual streamflow volumes.

\section{Introduction}

Elucidating continental patterns of annual streamflow volume changes in the Anthropocene epoch, to confirm unequivocally the effects of climate change and human impact on water resources, has become a challenge in contemporary hydrology (Blöschl et al., 2019). Although the hydrological scientific community has undertaken a great effort, little research robustly demonstrates the ubiquitous and uniform trend in European annual streamflow volumes (e.g., Mediero et al., 2014; Alfieri et al., 2015; Hodgkins et al., 2017; Blöschl et al., 2019). Most studies have identified the following two separate trends, both from recent observations and using model projections sensitive to climate change: reduced flows in southern and eastern Europe (e.g., Stahl et al., 2010; Caloiero and Veltri, 2019) and increased flows in central and northern Europe (up to $\pm 45 \%$ after 1962, according to Teuling et al., $2019 ;-10 \%$ to $30 \%$ and $+10 \%$ to $40 \%$, respectively, by the year 2050 , under the Special Report on Emissions Scenarios A1B, according to Milly et al., 2005). Lehner et al. (2006) identified large critical regions in southern and southeastern Europe for which significant changes in river flow drought are expected, and Feyen and Dankers (2009) projected increases in streamflow drought severity and persistence in most parts of Europe. 
Models have also highlighted a reduction through time of areas with increased runoff and an expansion of those with decreased runoff (e.g., a north-bound expansion of drying in the Mediterranean area; Milly et al., 2005). Similar trends were also found when analyzing trends in zero-flow days (Thober et al., 2018) and peak flows or flooding frequency, although there was high sensitivity to catchment size (Bertola et al., 2020). The majority of such changes have been attributed to changes in precipitation, with a less important role for land use and evapotranspiration change (Teuling et al., 2019).

Seasonal flows were also found to experience significant changes (Bard et al., 2015; Bormann and Pinter, 2017). Positive trends were found in the winter months in most catchments. A marked shift towards negative trends was observed in April, gradually spreading across Europe to reach a maximum extent in August. Low flows have decreased in most regions where the lowest mean monthly flow occurs in summer, with some exceptions in catchments buffered by a large groundwater storage capacity (e.g., Fleig et al., 2010; Laizé and Hannah, 2010). Bates et al. (2008) summarized some European studies that have found generally similar but more spatially explicit patterns, including, for example, decreasing future summer flow in central and eastern Europe. Also, models sensitive to climate change project that the peak in discharge will occur approximately 1 month earlier due to increased temperatures and earlier snowmelt in the future, with changes that are much more pronounced and statistically significant for all months under RCP8.5 compared to RCP4.5 (Lobanova et al., 2018).

Most studies, however, are based on observations limited to the second half of the 20th century (Piniewski et al., 2018; Renard et al., 2008; Birsan et al., 2005; KLIWA, 2003; Schmocker-Fackel and Naef, 2010; Demeterova and Skoda, 2005, 2009; Fiala, 2008; Fiala et al., 2010; Teuling et al., 2019). In addition, several studies highlighted the extreme sensitivity of river streamflow to data selection, methods of trend detection, and the time window for the analysis (Stahl et al., 2010). Kundzewicz et al. (2005, 2020) advocated particular caution in interpreting streamflow trend signals resulting from a restricted number of stations with a small recording period, as even small gaps in the data time series or missing values could alter the significance of the statistical tests. Finally, even though trends highlighted by the literature are broadly consistent with the spatial patterns of evapotranspiration and precipitation change, the effect of climate change on hydrology at the river basin scale is complex. Largescale climate or hydrological models can reproduce broad patterns but are still unable to capture all relevant spatially distributed characteristics of physical catchment structures and associated processes, particularly in regimes with storage and release of water across the seasons (Stahl et al., 2010). Also, extending the analysis to longer time series might reveal unexpected influences from long-term climate variability modes, such as the North Atlantic Oscillation (Hannaford et al., 2013; Steirou et al., 2017) or expected changes in the Atlantic Meridional Overturning Circulation (Brocca et al., 2020), which might introduce spurious trends in analyses focusing on shorter time spans. Finally, noise can be introduced by human modification and appropriation of streamflow, which may also reverse forecasted changes in river flow (Forzieri et al., 2014).

Based on this background, it appears more useful to solicit large-scale studies in order to investigate predominant annual streamflow volume continental trends, which can provide a basis for understanding processes in regional hydrology. In particular, a special effort should be made to focus the analysis of the river flow time series over the Mediterranean area, which is almost always overlooked in trend studies due to the lack of river discharge data.

To achieve this aim, reliable networks of river streamflow measures in near-natural catchments are necessary. Several countries in the world have nowadays developed reference hydrometric networks composed of gauging stations with long and uninterrupted river flow records (Burn et al., 2012; Hannah et al., 2010). Such networks are generally managed and maintained by regional authorities or civil protection agencies and are composed of gauging stations for measuring the river water level (stage) combined with updated stage-discharge relationships (Kundzewicz and Robson, 2004). Data sets for large parts of Europe are available nowadays (e.g., for alpine, Mediterranean, continental, Baltic and Nordic regions), with thousands of stations and records which start from the 19th century. This amount of data covers a wide variety of catchments, from small (a few hundreds of hectares) to large (thousands of square kilometers; Steiru et al., 2017; Mediero et al., 2014). Nevertheless, the development of the hydraulic infrastructures in $\mathrm{Eu}-$ rope associated with the increase in population density and a lack of undisturbed natural environments makes the measurements less representative of the natural flow conditions (Bertola et al., 2020). Recording a high-quality streamflow measurements unaffected by potential anthropogenic disturbances and which is suitable for large-scale trend analysis is a major challenge (Hisdal et al., 2001, 2007; Shorthouse and Arnell, 1997).

The need for a reference river flow data set of near-pristine catchments has been largely recognized worldwide and has been supported by some international programs. The most famous is the FRIEND program, an initiative supported by the UNESCO International Hydrological Programme (IHO), the European Water Archive (EWA), and the European Environmental Agency (EPA), which allows us to share scientific information to improve methods applicable in water resources planning and management (Arnell, 1999). However, updating streamflow measures and installing new flow meters is not straightforward in Europe. In particular, the organization has become complicated by regional and local jurisdictions, including political, administrative, and technical constraints, as well as economical barriers (Viglione et al., 2010). In the 
absence of national or regional data sets, the Global Runoff Data Center (GRDC) can represent a valid global database of large continental river flow measures in Europe (Haddeland et al., 2010; Stahl et al., 2010), despite most studies preferring to combine data with model-derived predictions to fill gaps and reconstruct the time series to have a comparable length (Dai et al., 2009). Hence, the challenge is combining the results of regional and national streamflow measures into a pan-European-scale study of annual streamflow volume trends which uses a consistent methodology based on a consolidated and validated continental river flow data set. In fact, detecting and assessing European trends in annual streamflow volumes can represent a strategic point in water management policies both in terms of flood security, drought and desertification control (Ban et al., 2015). National and basin authorities could plan tailored irrigation methods in targeted areas and encourage the use of non-conventional water for irrigation or funding modernization of irrigation systems where streamflow negative trends occur (Rogger et al., 2017). On the contrary, authorities could promote the use of natural water retention measures (http://nwrm.eu/, last access: 22 October 2021) and best management practices (Urbonas and Stahre, 1993) in territories affected by a positive trend (Brooks, 2013).

The purpose of the present study is, therefore, to provide an analysis of the spatiotemporal variability in annual streamflow volumes on the European continent, starting from the analysis of consolidated observations over a long time period with a particular emphasis on flow regimes relevant for water resource management, especially in Mediterranean areas. Specifically, the added value of the present work is (i) to characterize annual streamflow volume trends over the entire European continent, using a long time period of actual river flow observations, (ii) to deepen the analysis on annual streamflow volume trends in the Mediterranean area, which is under increasing pressure due to climate change effects, (iii) to determine whether evidence of a marked inversion point in the annual streamflow volume availability can be found directly in the observations, and (iv) to discuss the outcomes of the present study with previous investigations.

\section{Material and methods}

\subsection{River flow data selection and processes}

A large data set of daily river streamflow records measured by 3913 gauged stations over the entire European continent was analyzed to characterize the continental patterns of the river flow regime over time. The original data set, compiled by the authors, merges stations from five different databases, i.e., the Global Runoff Data Base (GRDC), the European Water Archive (EWA); the Italian ISPRA HIS national database (http://www.hiscentral.isprambiente. gov.it/hiscentral/default.aspx, last access: 22 October 2021), the Portuguese national database (http://snirh.pt/, last access: 22 October 2021) and the Spanish national database (http://ceh-flumen64.cedex.es/anuarioaforos/default.asp, last access: 22 October 2021), consisting of observed streamflow, recorded between 1900 and 2013. Unfortunately, not all the gauged stations have been working at the same time (Fig. 1) and with a consistent and reliable data set.

To assess the reliability of streamflow daily values of each gauged station of the original data set, a quality control and a homogeneity assessment were performed, according the methodologies described in Buishand (1984), Chu et al. (2020), Ghiggi et al. (2021), and Kundzewicz et al. (2015).

The quality control was conducted in succession on daily and aggregated time series, using the following steps reported in Gudmundsson and Seneviratne (2016):

i. identifying evident malfunctions, consistent gaps, and hydrograph disturbances, such as the presence of dams or reservoirs, by a visual hydrograph inspection;

ii. excluding catchments with a drainage area larger than $100000 \mathrm{~km}^{2}$ to minimize the possibility that human actives can significantly cause disturbances to the streamflow time series (Piniewski et al., 2018);

iii. removing values with negative daily streamflow values;

iv. removing time series with more than 2 years of missing data.

The homogeneous detection of the data series was performed by combining the following four different tests (Gudmundsson et al., 2017): (i) the standard normal homogeneity test of Alexandersson (1986), (ii) the Buishand range test (Buishand, 1982), (iii) the Pettitt test (Pettitt, 1979), and (iv) the von Neumann ratio test (Von Neumann, 1941). Homogeneity tests were carried out using the "iki.dataclim" statistical package for R (Orlowsky et al., 2014). The streamflow time series were considered as being consistent when the null hypothesis at the $1 \%$ level was accepted at least in three of four tests (ECA \& D; Gudmundsson and Seneviratne, 2016; Peña-Angulo et al., 2019).

Despite the fact that potential levels of human-induced alterations in the river flow regime could be still present in time series data after the application of the aforementioned controls, a certain degree of disturbance can be tolerated (Murphy et al., 2013). In order to further reduce the disturbance, high flow conditions were not investigated, and we focused the analysis on annual streamflow volumes.

The application of quality control and homogeneity tests led us to discard 428 series of data. Thus, 3485 stations, providing at least 61 years of flow records, were selected and assembled into a data set that guarantees the best balance between the necessity to investigate a data set that is as large as possible (which covers a large part of the continent and 


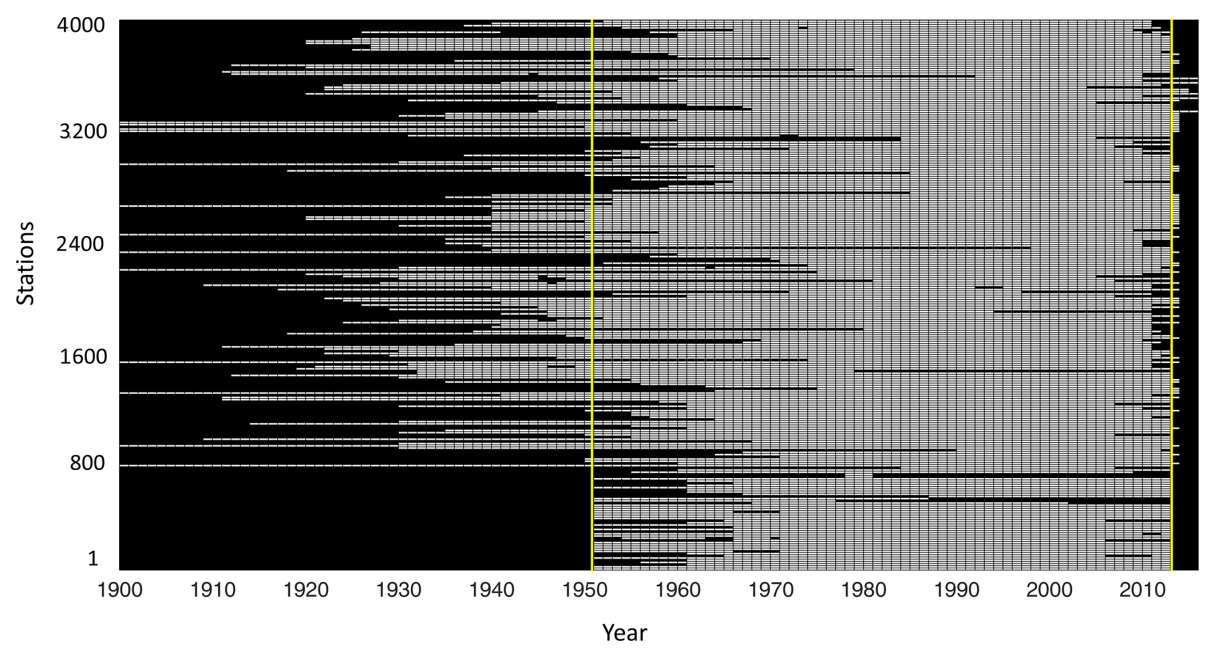

Figure 1. Available years for the 3913 gauged stations. Vertical lines in yellow indicate the selected common study period (1950-2013).

Table 1. Overall characteristics of the examined basins.

\begin{tabular}{|c|c|c|c|}
\hline $\begin{array}{l}\text { Area } \\
\text { range } \\
\left(\mathrm{km}^{2}\right)\end{array}$ & $\begin{array}{r}\text { Percentage } \\
\text { of basins } \\
(\%)\end{array}$ & $\begin{array}{r}\text { Elevation } \\
\text { of basin } \\
\text { centroid } \\
\text { (m a.s.l.) } \\
\text { maximum - } \\
\text { minimum } \\
\text { (mean) }\end{array}$ & $\begin{array}{r}\text { Annual } \\
\text { streamflow } \\
\text { volume } \\
\left(10^{6} \mathrm{~m}^{3}\right) \\
\text { maximum - } \\
\text { minimum } \\
\text { (mean) }\end{array}$ \\
\hline $0-100$ & 30 & $2900-2(677)$ & $247.40-40.81(112.78)$ \\
\hline $100-200$ & 21 & $2700-19(510)$ & $241.85-44.15$ (139.03) \\
\hline $200-300$ & 13 & $2170-30(320)$ & $306.06-52.82(154.01)$ \\
\hline $300-400$ & 10 & $2200-11(621)$ & $338.43-68.38$ (188.40) \\
\hline $400-500$ & 7 & $1980-10(321)$ & $431.28-80.36(246.83)$ \\
\hline $500-600$ & 6 & $1970-21(452)$ & $526.43-106.32(307.59)$ \\
\hline $700-800$ & 5 & $1856-31(322)$ & 554.09-90.12 (312.32) \\
\hline 800-900 & 3 & $1879-12(398)$ & $671.32-98.89(363.59)$ \\
\hline $900-1000$ & 3 & $1900-10(532)$ & $889.22-143.21(488.03)$ \\
\hline$>1000$ & 2 & $1970-8(601)$ & $931.21-150.01$ (498.98) \\
\hline
\end{tabular}

a nearly complete period of analysis) and to detect historical variability. The location of the different gauged stations is reported in Fig. 2 on a physical European map, while some statistics are reported in Table 1. The selected gauged stations belong to more than 40 European countries, especially those over the Mediterranean basin. In fact, about one-third are located in Spain, France and Italy. The data set provided time series data from 1950 to 2013 (i.e., a 63-year study period has been considered as being the maximum record length able to guarantee a uniformity in the series of data among the stations, as reported in Fig. 1).

About $90 \%$ of stations belongs to catchments with a size less than $1000 \mathrm{~km}^{2}$, of which more than $50 \%$ range from 1 to $200 \mathrm{~km}^{2}$. The temporal autocorrelation level of the selected near-natural daily streamflow series was verified by calculating the lag-1 serial autocorrelation coefficient with a $95 \%$ of confidence bound, as suggested by Khaliq et al. (2009),
Kulkarni and von Storch (1995), and von Storch (1995). All autocorrelation coefficients were found to be included in the confidence bounds, as shown in Fig. 3, and, therefore, they can be considered as being ready for the trend identification.

\subsection{Trend detection}

The trend magnitude of a hydro-meteorological series of data is usually estimated using the Theil-Sen estimator (Theil, 1950; Sen, 1968), a non-parametric test usually adopted to indicate the monotonic trend and amplitude of change per unit of time. It is a robust estimate of the magnitude of a trend in hydrological and climatic time series, as demonstrated in the scientific literature (e.g., Kundzewicz and Robson, 2004; Stahl et al., 2010; Burn et al., 2012). In the present study, the slope of the Theil-Sen line, known as the Theil-Sen slope or Sen's slope, was calculated on the annual anomalies in streamflow volumes, which is an alternative modality with respect to the common application on direct streamflow data (Birsan et al., 2005). The annual anomalies in volumes were detected by comparing them with the baseline obtained by averaging annual streamflow volumes in the entire period of observation for each station. This strategy allows us to emphasize trends, minimizing the random errors derived from uncorrected measures or unexpected signals, as already tested by Pandžić and Trninić (1992). A positive anomaly indicates that the observed annual streamflow volume is greater than the baseline, while a negative anomaly indicates the observed annual streamflow volume is lower than the baseline. The value of each anomaly was divided for the catchment area, thus obtaining volume anomalies per unit of the area. Moreover, the significance of the annual streamflow volume trend was tested by adopting a non-parametric statistical approach based on the Mann-Kendall (MK; Mann, 1945; Kendall, 1975) test. Such a test has already shown its robustness in trend detection in the case of non-normally dis- 


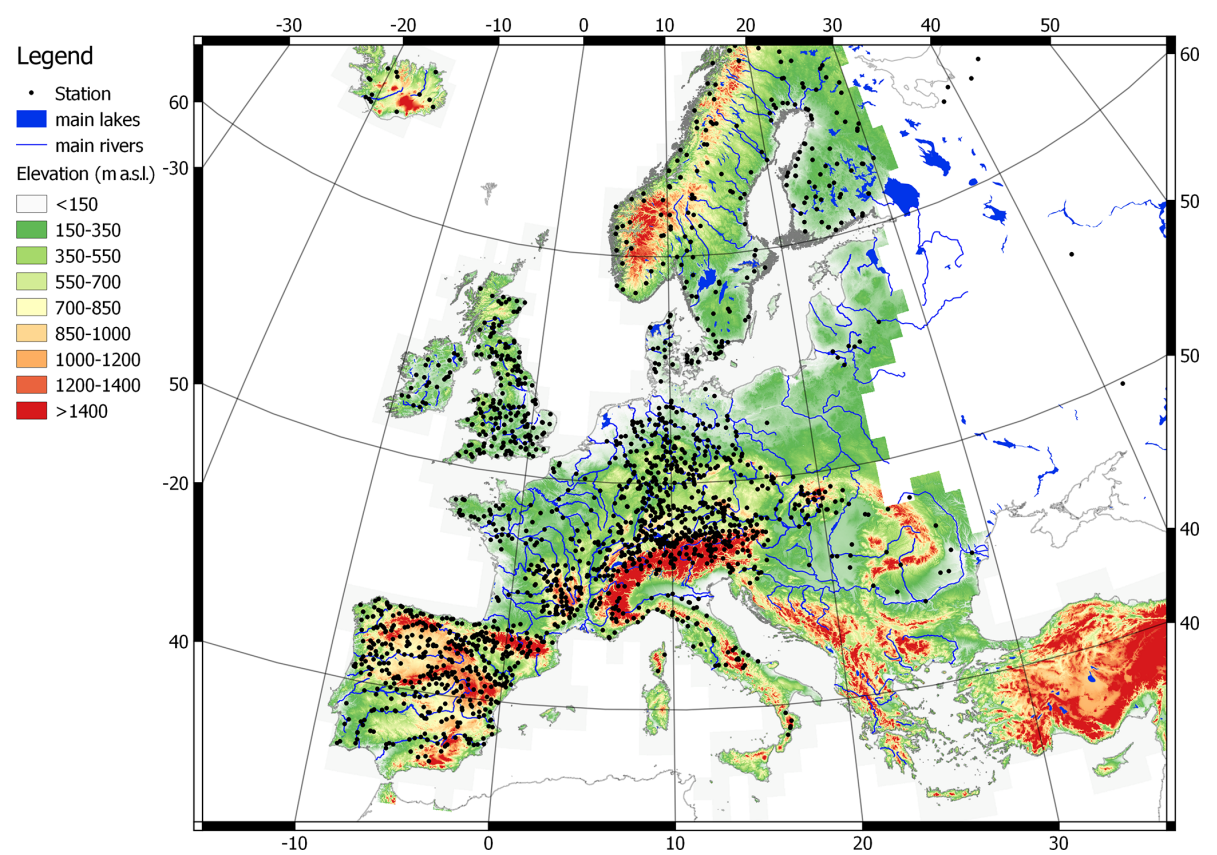

Figure 2. Map of the European study area. The digital elevation model (DEM), main rivers and lakes, as well as the position of the gauged stations are presented.

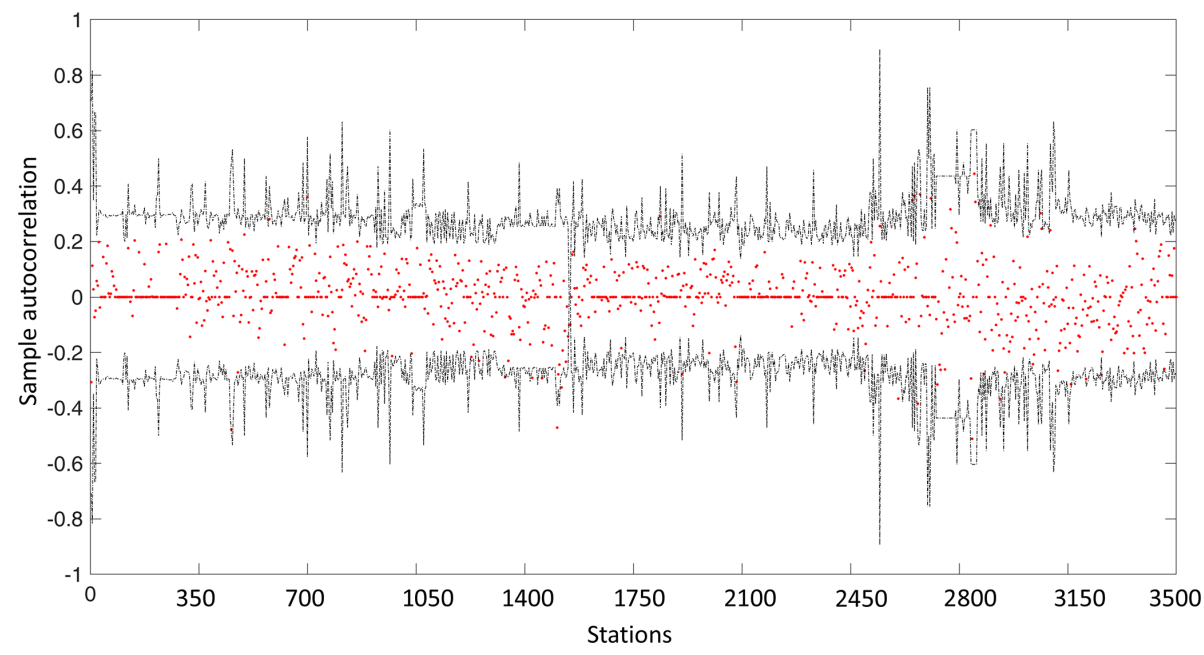

Figure 3. Sample autocorrelations. The red points are the value of the lag-1 autocorrelation coefficient, whereas black dotted lines represent the $95 \%$ confidence bounds.

tributed data, such as the meteorological and hydrological series (e.g., Yue and Wang, 2002; Yue et al., 2003; Yue and Pilon, 2004; Piniewski et al., 2018). In particular, if the result of the test is returned as $H=1$, it indicates a rejection of the null hypothesis (i.e., presence of trend) at the alpha significance level (here assumed to be equal to 0.05). Conversely, if $H=0$, then it indicates a failure to reject the null hypothesis at the alpha significance level (i.e., no presence of a trend). In the present study, we decided to maintain the integrity of the data set by focusing on the same time frame for the entire study domain without splitting it into periods of different lengths. This procedure was already proposed in the study of Durocher et al. (2019), who preferred to discard all those time series with missing data over a threshold rather than consider different time windows. 
Table 2. Percentage of significant (i.e., 3310 stations) positive and negative trends in annual streamflow volumes in the European macro-regions.

\begin{tabular}{lrrr}
\hline Region & $\begin{array}{r}\text { No. of } \\
\text { stations }\end{array}$ & $\begin{array}{r}\text { Positive } \\
\text { trend }\end{array}$ & $\begin{array}{r}\text { Negative } \\
\text { trend }\end{array}$ \\
\hline Boreal & 323 & 307 & 16 \\
Continental & 694 & 472 & 222 \\
Atlantic & 1191 & 846 & 345 \\
Mediterranean & 1102 & 88 & 1014 \\
\hline Total & 3310 & 1713 & 1597 \\
\hline
\end{tabular}

\section{Results and discussion}

\subsection{Annual streamflow volume trends in Europe}

The anomalies in the annual streamflow volumes for each gauged station were calculated, and in Fig. 4a and b, an example of positive and negative trend evaluated thought the slope of the Theil-Sen line and confirmed by MK test for two stations located in central Europe is reported.

Results found that, in $95 \%$ of the European gauged stations (i.e., 3310 stations), the MK test confirmed the presence of a trend in annual streamflow volumes. In general, $70 \%$ positive and $30 \%$ negative trends in annual streamflow volume anomalies are recognized, with a clear positive trend in the northern regions and negative trend in the southern ones, as shown in Fig. 5. These results are certainly representative of the selected time window, despite not all gauged stations providing full-length series during the same period, because the data selection maintains a trade-off between the record length and spatial coverage over the continent, allowing the removal of those limited by a wide time series gap or evident uncertainties/inconsistencies.

By adopting the subdivision of the European continent in the four macro-regions, as provided by Gudmundsson et al. (2017) and Fernandez-Carrillo et al. (2019), i.e., boreal, continental, Atlantic, and Mediterranean areas, the results show a marked negative trend in annual streamflow volumes, especially in Mediterranean region, with about $90 \%$ of the stations having a negative trend. The percentages of positive and negative trends for each macro-region are summarized in Table 2. The results reveal that, on average, a decrease in the annual streamflow volume of about $-1 \times 10^{3} \mathrm{~m}^{3} /\left(\mathrm{km}^{-2} \mathrm{yr}^{-2}\right)$ in Mediterranean areas and an increase of about $0.5 \times 10^{3} \mathrm{~m}^{3} /\left(\mathrm{km}^{-2} \mathrm{yr}^{-2}\right)$ in northern regions occur.

The spatial pattern of the annual streamflow volume trend, reported in Fig. 5, appears broadly consistent with the findings obtained in the previous sub-regional studies of Piniewski et al. (2018), Ilnicki et al. (2014), Bormann and Pinter (2017), Bard et al. (2015), Milly et al. (2005), Milliman et al. (2008), Manabe et al. (2004), and Dai et al. (2009).
Although based on observed streamflow time series with many differences (i.e., time interval, time length, methodology of measurement, etc.), such as sometimes being affected by local river regulation or hydraulic infrastructure and often completed with model-derived data, these studies predominantly found positive trends in regions close to the Atlantic Ocean and North Sea and negative trends in areas close to the Mediterranean Sea.

The European spatial pattern of the annual streamflow volume trend also appears congruent with the observed European long-term precipitation and temperature changes, as shown in Fig. 6a and b. Specifically in Fig. 6a, the annual streamflow volume trends were overlapped with the daily mean precipitation trend maps obtained by E-OBS gridded data set 20.0e (https://www.ecad.eu/, last access: 22 October 2021 - Morice et al., 2012) for the same selected time period of daily streamflow series (i.e., 1950-2013).

Concerning precipitation changes, the Mediterranean regions are affected by a marked negative trend (even below $-3 \mathrm{~mm}$ per decade), while the boreal and Atlantic regions are characterized by a positive trend which can overcome $10 \mathrm{~mm}$ per decade. The spatial distribution over the continent, of both patterns, appears perfectly congruent with the findings in annual streamflow volumes, as shown in Fig. 6 .

Despite the spatial annual streamflow volume trend being very clear at a synoptic scale (i.e., increase in annual streamflow volumes in northern Europe and vice versa in southern Europe), in some local cases it can be the opposite. In northern Germany, the Scandinavian peninsula, and the eastern part of the Alps, positive and negative annual streamflow volume trends are mixed. This can be closely linked to complexity of snowmelt processes in glacier or mountain basins and the potential interactions between groundwater levels and river flows, as suggested by Renard et al. (2008), Birsan et al. (2005), and Pelliciotti et al. (2010). The authors found that, in some regions, such as southeastern England, northeastern France, and Denmark, the contribution of the aquifer to streamflow is high especially in the summer periods. Various studies, moreover, have demonstrated that the mechanisms of interactions between groundwater and river flow contribute to moderate the influence of climate change drivers on streamflow; conversely, basins with less productive aquifers show a more direct response to climate drivers (Fleig et al., 2010; Laizé and Hannah, 2010).

Concerning air temperature changes, the works of Stagge et al. (2017), Vicente-Serrano et al. (2014), Spinoni et al. (2015), Zeng et al. (2012), Willems (2013), and Madsen et al. (2014) confirm a global increase in mean temperatures, with a marked trend in Mediterranean areas, where air temperature is expected to increase by up to $0.3^{\circ} \mathrm{C}$ per decade (as found in this study). The increase in air temperature directly impacts glacierized and snow-dominated basins, where it may be responsible for the increase in runoff volume during the last 60 years due to the loss of ice masses (Sommer et al., 2020); however, depending on the basin elevation and trend 

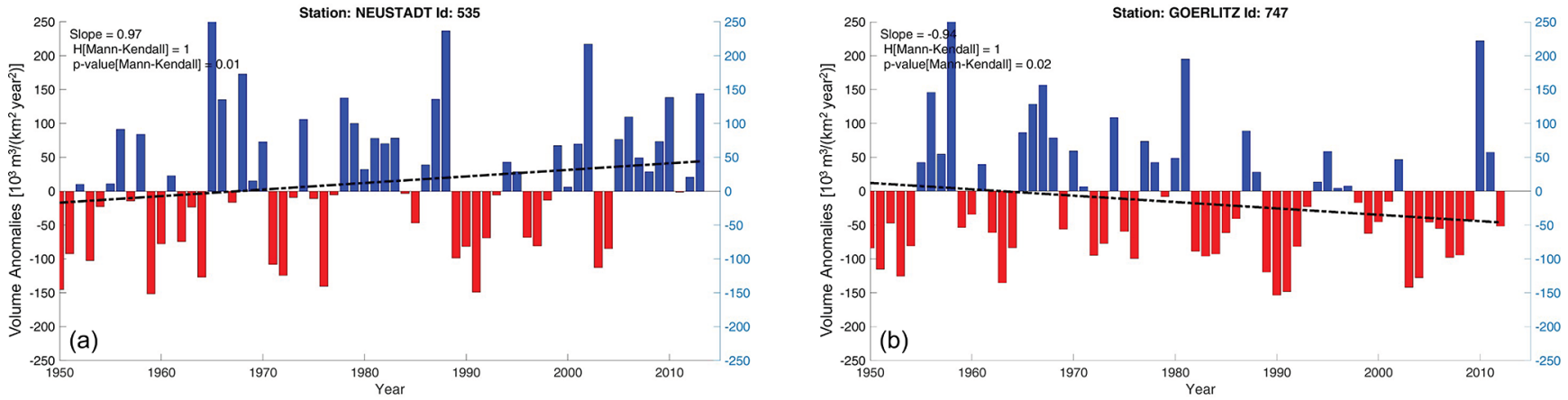

Figure 4. Anomalies in the annual streamflow volumes for the station of Neustadt (a) and Goerlitz (b). In the graphs, the slope of the Theil-Sen line, $H$, and $p$ values of the Mann-Kendall test are also reported.

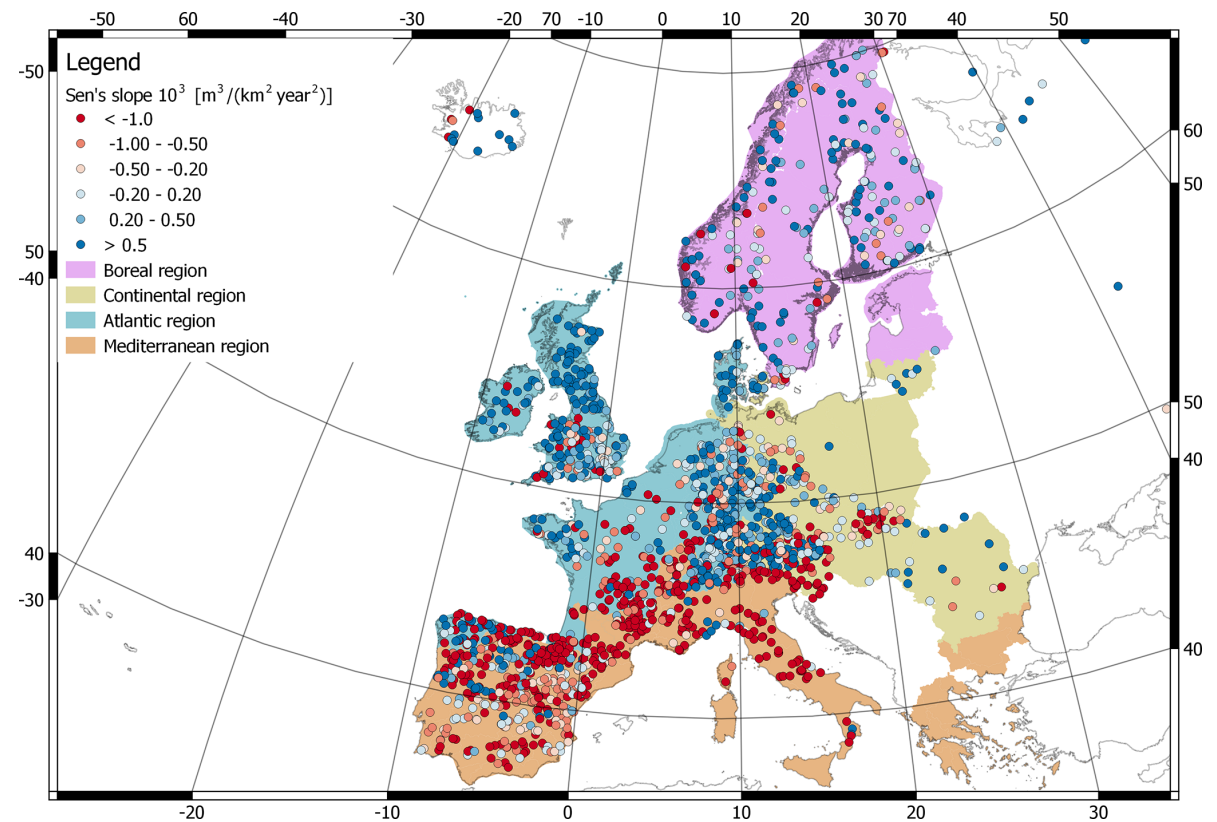

Figure 5. Annual trend of the streamflow volume anomalies on the European continent subdivided into boreal, continental, Atlantic, and Mediterranean regions. Only significant trends are shown.

in precipitation, some glaciers might have lost some sensitivity to an increased runoff production as a consequence of higher temperatures since there has not been more ice to melt and because, at high elevations, the temperature might be not warm enough to counterbalance the precipitation trend. In summary, for glacierized basins (or those that use to be) there might be a causal effect of temperature on increased runoff volume (although this effect might have lost in time for some of them, as explained below), while, for the others, precipitation again seems to be the main driver of the runoff trend, as can be seen over the Alps by the contrasting trend found between the Italian side (negative) and continental side (positive), which reflects the trend in precipitation. On the other hand, a temperature increase can negatively impact runoff over energy-limited environments by increasing evapotranspiration (Teuling et al., 2013; Avanzi et al., 2020), so some catchments might have experienced a reduced runoff trend as a consequence of this warming. This might explain the negative runoff trend found for some basins at high latitudes.

\subsection{Annual streamflow volume trend in Mediterranean area}

Focusing on the main Mediterranean river catchments (according to the European Environmental Agency classification), the number of stations with a positive and negative Theil-Sen slope for each catchment was computed, and the results are reported in Fig. 7. In all main river basins in Spain, France, and Italy, negative trends of annual streamflow volumes prevail. A larger magnitude of negative annual streamflow volume trends is found in the Garonne and Rhone river 

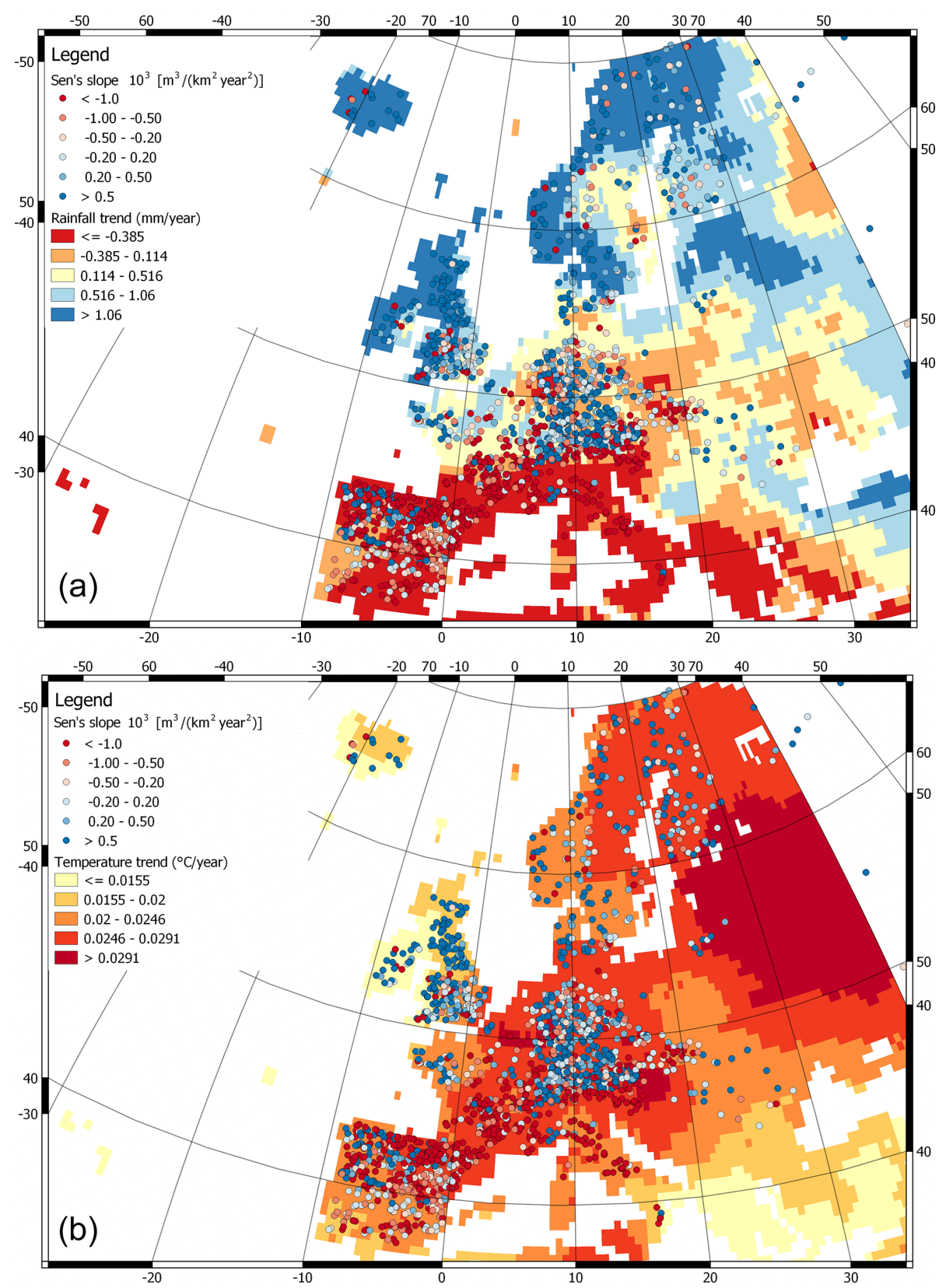

Figure 6. Comparison between the annual streamflow volume trends and daily precipitation (including the snow-to-liquid equivalent) (a) and mean temperature (b) trends over the European continent. Only significant trends are shown.

basins, respectively, of about $-2.2 \times 10^{3} \mathrm{~m}^{3} /\left(\mathrm{km}^{-2} \mathrm{yr}^{-2}\right)$ and $-3 \times 10^{3} \mathrm{~m}^{3} /\left(\mathrm{km}^{-2} \mathrm{yr}^{-2}\right)$. No basin with a marked artifact trend is found, as demonstrated by the very close distances of the 25th and 75th percentiles from the median slope value, which, thus, confirms the trend homogeneities inside each basin.

A negative trend over the entire Mediterranean basin is also confirmed by the analysis performed on the mean annual streamflow volume produced in this area. The annual streamflow volumes of each station were standardized by their mean value, and then the standardized annual streamflow volumes of all stations were averaged. The result is reported in Fig. 8, where the standardized annual streamflow volumes are smoothed by a simple rolling average, with a sliding window of 5-year length, shown along with the 25 th and 75 th percentile trends. When the standardized annual streamflow volume is greater than 1 , it means that the annual streamflow volume is greater than the average of annual streamflow volumes and vice versa if standardized annual streamflow volume is lower than 1 . The former case can 


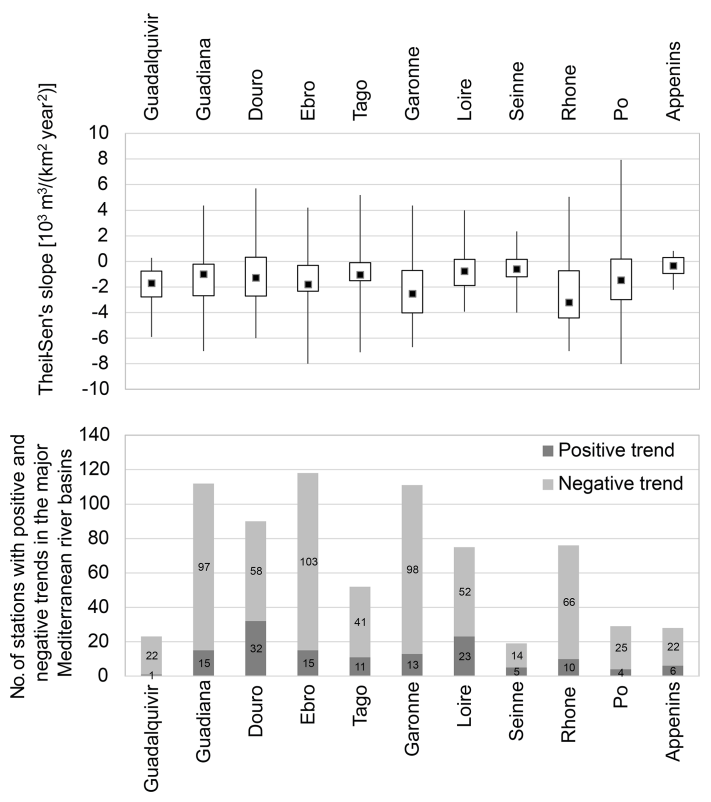

Figure 7. Number of stations with positive and negative annual streamflow volume trends in the main Mediterranean river basins. The box plot of the Theil-Sen slope for each catchment is also reported.

be considered as being a positive signal of annual streamflow volume exceedance, whereas in the latter an annual streamflow volume deficit is found. Figure 8 shows a change in the annual streamflow volume pattern between 1980 and 1985, where the values move from positive to negative availabilities with respect to the mean of the annual streamflow volume observations. This finding is consistent with the results found by Hannaford et al. (2013) on the marked decrease in low flow regimes in southern Europe in the last 30 years and with the conclusions found in the work of the International Panel of Climate Change (IPCC) on climate change prospective (IPCC, 2007), which highlighted how, in the Northern Hemisphere, climate change effects that reduce water resource availability have increased notably from the post- 1980 period.

\section{Conclusions}

This study closes the gap between regional studies on annual streamflow volume trend and a continental-scale pattern of its spatiotemporal variability. Starting from a data set constituted by more than 3000 gauged stations over more than 40 countries across Europe, anomalies in the annual streamflow volume were computed, and the Theil-Sen line slope was evaluated for each catchment over a recorded period from 1950 to 2013. A clear and undisputed trend pattern in the annual streamflow volume is recognized by the statistical analysis, showing marked negative trends in the Mediterranean areas and positive trends in the northern regions of

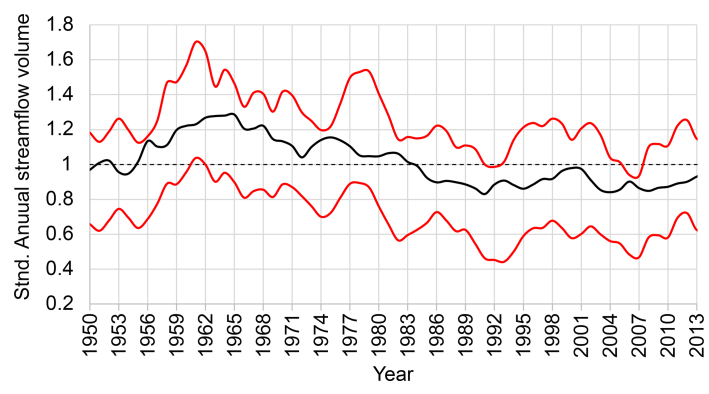

Figure 8. Standardized annual streamflow volume pattern from 1950 to 2013. The black line shows the simple rolling average of the standardized annual streamflow volume behavior over the entire Mediterranean area. Red lines show the 25 th and 75 th percentiles of the standardized annual streamflow volume series.

Europe. All main Mediterranean river basins reveal negative trends in the annual streamflow volume, with an expected decrease in the annual streamflow volume of about $-1 \times$ $10^{3} \mathrm{~m}^{3} /\left(\mathrm{km}^{-2} \mathrm{yr}^{-2}\right)$. On the contrary, in the northern regions of Europe, a positive increase in annual streamflow volume is expected to be, on average, about $0.5 \times 10^{3} \mathrm{~m}^{3} /\left(\mathrm{km}^{-2} \mathrm{yr}^{-2}\right)$. This trend pattern agrees with the increase in temperatures and the decrease in precipitation volumes detected by longterm observations on European continent. Indeed, these observations confirm an increase in drought situations in the southern regions of Europe, whereas they reveal an increase in precipitation volumes and runoff production in northern European countries. In the Mediterranean area, the effect of climate change has caused an inversion of the annual streamflow volume availability with respect to the mean of observations, i.e., from positive to negative values, starting from about 1985. In the recent 30-year period (1985-2013), the streamflow volumes are consistently lower than the average availability of the period 1950-2013.

The results of this study, therefore, can pave the way for more detailed quantitative analysis of annual streamflow volume variability (especially during different seasons) to meet the needs of managing water resources in agricultural, industrial, and civil sectors.

Code availability. The codes are available by contacting the authors.

Data availability. All data used in this work are of public domain and freely downloadable at the links quoted in the text.

Author contributions. SC led the investigation, validation, data curation, and visualization and wrote the original draft. AC took responsibility for the investigation, validation, and visualization and reviewed and edited the paper. $\mathrm{CM}$ and $\mathrm{GV}$ were involved with the conceptualization and investigation and reviewed and edited the pa- 
per. DM developed the methodology, did the formal analysis, curated the data, reviewed and edited the paper, acquired the funding, and administered the project. LB conceptualized the research, developed the methodology, acquired the resources, reviewed and edited the paper, and supervised the project.

Competing interests. The authors declare that they have no conflict of interest.

Disclaimer. Publisher's note: Copernicus Publications remains neutral with regard to jurisdictional claims in published maps and institutional affiliations.

Special issue statement. This article is part of the special issue "Changes in the Mediterranean hydrology: observation and modeling". It is not associated with a conference.

Acknowledgements. This study was developed in the context of IrriGate project "Toward a smart and flexible irrigation management in gravity-fed irrigation contexts" funded by Regione Lombardia (PSR 1.2.01; year 2019).

Financial support. This research has been supported by the Regione Lombardia (grant no. 201901319885).

Review statement. This paper was edited by María José Polo and reviewed by two anonymous referees.

\section{References}

Alexandersson, H.: A homogeneity test applied to precipitation data, J. Climatol., 6, 661-675, 1986.

Alfieri, L., Burek, P., Feyen, L., and Forzieri, G.: Global warming increases the frequency of river floods in Europe, Hydrol. Earth Syst. Sci., 19, 2247-2260, https://doi.org/10.5194/hess-19-22472015, 2015.

Arnell, N. W.: A simple water balance model for the simulation of streamflow over a large geographic domain, J. Hydrol., 217, 314-335, 1999.

Avanzi, F., Rungee, J., Maurer, T., Bales, R., Ma, Q., Glaser, S., and Conklin, M.: Climate elasticity of evapotranspiration shifts the water balance of Mediterranean climates during multi-year droughts, Hydrol. Earth Syst. Sci., 24, 4317-4337, https://doi.org/10.5194/hess-24-4317-2020, 2020.

Ban, N., Schmidli, J., and Schär, C.: Heavy precipitation in a changing climate: does short-term summer precipitation increase faster?, Geophys. Res. Lett., 42, 1165-1172, https://doi.org/10.1002/2014GL062588, 2015.

Bard, A., Renard, B., Lang, M., Giuntoli, I., Korck, J., Koboltschnig, G., Janža, M., d'Amico, M., and Volken, D.:
Trends in the hydrologic regime of Alpine rivers, J. Hydrol., 529, 1823-1837, https://doi.org/10.1016/j.jhydrol.2015.07.052, 2015.

Bates, B. C., Kundzewicz, Z. W., Wu, S., and Palutikof, J. P. (Eds.): Climate change and water, Technical Paper of the Intergovernmental Panel on Climate Change, IPCC Secretariat, Geneva, 2008.

Bertola, M., Viglione, A., Lun, D., Hall, J., and Blöschl, G.: Flood trends in Europe: are changes in small and big floods different?, Hydrol. Earth Syst. Sci., 24, 1805-1822, https://doi.org/10.5194/hess-24-1805-2020, 2020.

Birsan, M.-V., Molnar, P., Burlando, P., and Pfaundler, M.: Streamflow trends in Switzerland, J. Hydrol., 314, 312-329, https://doi.org/10.1016/j.jhydrol.2005.06.008, 2005.

Blöschl, G., Hall, J., Viglione, A., Perdigão, R. A. P., Parajka, J., Merz, B., Lun, D., Arheimer, B., Aronica, G. T., Bilibashi, A., Boháč, M., Bonacci, O., Borga, M., Čanjevac, I., Castellarin, A., Chirico, G. B., Claps, P., Frolova, N., Ganora, D., Gorbachova, L., Gül, A., Hannaford, J., Harrigan, S., Kireeva, M., Kiss, A., Kjeldsen, T. R., Kohnová, S., Koskela, J. J., Ledvinka, O., Macdonald, N., Mavrova-Guirguinova, M., Mediero, L., Merz, R., Molnar, P., Montanari, A., Murphy, C., Osuch, M., Ovcharuk, V., Radevski, I., Salinas, J. L., Sauquet, E., Šraj, M., Szolgay, J., Volpi, E., Wilson, D., Zaimi, K., and Živković, N.: Changing climate both increases and decreases European river floods, Nature, 573, 108-111, https://doi.org/10.1038/s41586-019-1495-6, 2019.

Bormann, H. and Pinter, N.: Trends in low flows of German rivers since 1950: comparability of different low-flow indicators and their spatial patterns, River Res. Appl., 33, 1191-1204, https://doi.org/10.1002/rra.3152, 2017.

Brocca, L., Massari, C., Pellarin, T., Filippucci, P., Ciabatta, L., Camici, S., Kerr, Y. H., and Fernández-Prieto, D.: River flow prediction in data scarce regions: soil moisture integrated satellite rainfall products outperform rain gauge observations in West Africa, Scient. Rep., 10, 1-14, 2020..

Brooks, H. E.: Severe thunderstorms and climate change, Atmos. Res., 123, 129-138, https://doi.org/10.1016/j.atmosres.2012.04.002, 2013.

Buishand, T. A.: Some methods for testing the homogeneity of rainfall records, J. Hydrol., 58, 11-27, 1982.

Buishand, T. A.: Tests for detecting a shift in the mean of hydrological time series, J. Hydrol., 73, 51-69, 1984.

Burn, D. H., Hannaford, J., Hodgkins, G. A., Whitfield, P. H., Thorne, R., and Marsh, T.: Reference hydrologic networks II. Using reference hydrologic networks to assess climatedriven changes in streamflow, Hydrolog. Sci. J., 57, 1580-1593, https://doi.org/10.1080/02626667.2012.728705, 2012.

Caloiero, T. and Veltri, S.: Drought assessment in the Sardinia Region (Italy) during 1922-2011 using the standardized precipitation index, Pure Appl. Geophys., 176, 925-935, 2019.

Chu, H., Wei, J., and Wu, W.: Streamflow prediction using LASSO-FCM-DBN approach based on hydrometeorological condition classification, J. Hydrol., 580, 124253, https://doi.org/10.1016/j.jhydrol.2019.124253, 2020.

Dai, A., Qian, T., Trenberth, K. E., and Milliman, J. D.: Changes in continental freshwater discharge from 1948 to 2004, J. Climate, 22, 2773-2792, https://doi.org/10.1175/2008JCLI2592.1, 2009. 
Demeterová, B. and Škoda, P.: Minimal discharges at the Slovak riversin the period 1961-2000 at the stations of National Climate Programme, Meteorologicky Casopis, 3, 155, 2005.

Demeterová, B. and Škoda, P.: Low flow in selected streams of Slovakia, J. Hydrol. Hydromech., 57, 55-69, https://doi.org/10.2478/v10098-009-0006-0, 2009.

Durocher, M., Requena, A. I., Burn, D. H., and Pellerin, J.: Analysis of trends in annual streamflow to the Arctic Ocean, Hydrol. Process., 33, 1143-1151, 2019.

Fernandez-Carrillo, A., de la Fuente, D., Rivas-Gonzalez, F. W., and Franco-Nieto, A.: A Sentinel-2 unsupervised forest mask for European sites, in: Earth Resources and Environmental Remote Sensing/GIS Applications X, International Society for Optics and Photonics, Strasbourg, France, https://doi.org/10.1117/12.2533040, 2019.

Feyen, L. and Dankers, R.: Impact of global warming on streamflow drought in Europe, J. Geophys. Res.-Atmos., 114, D17116, https://doi.org/10.1029/2008JD011438, 2009.

Fiala, T.: Statistical characteristics and trends of mean annual and monthly discharges of Czech rivers in the period 1961-2005, J. Hydrol. Hydromech., 56, 133-140, 2008.

Fiala, T., Ouarda, T. B. M. J., and Hladný, J.: Evolution of low flows in the Czech Republic, J. Hydrol., 393, 206-218, https://doi.org/10.1016/j.jhydrol.2010.08.018, 2010.

Fleig, A. K., Tallaksen, L. M., Hisdal, H., and Hannah, D. M.: Regional hydrological drought in north-western Europe: linking a new Regional Drought Area Index with weather types, Hydrol. Process., 25, 1163-1179, https://doi.org/10.1002/hyp.7644, 2011.

Fleig, A. K., Tallaksen, L. M., James, P., Hisdal, H., and Stahl, K.: Attribution of European precipitation and temperature trends to changes in synoptic circulation, Hydrol. Earth Syst. Sci., 19, 3093-3107, https://doi.org/10.5194/hess-19-3093-2015, 2015.

Forzieri, G., Feyen, L., Rojas, R., Flörke, M., Wimmer, F., and Bianchi, A.: Ensemble projections of future streamflow droughts in Europe, Hydrol. Earth Syst. Sci., 18, 85-108, https://doi.org/10.5194/hess-18-85-2014, 2014.

Ghiggi, G., Humphrey, V., Seneviratne, S. I., and Gudmundsson, L.: G-RUN ENSEMBLE: A Multi-Forcing ObservationBased Global Runoff Reanalysis, Water Resour. Res., 57, e2020WR028787, https://doi.org/10.1029/2020WR028787, 2021.

Gudmundsson, L. and Seneviratne, S. I.: Observation-based gridded runoff estimates for Europe (E-RUN version 1.1), Earth Syst. Sci. Data, 8, 279-295, https://doi.org/10.5194/essd-8-279-2016, 2016.

Gudmundsson, L., Seneviratne, S. I., and Zhang, X.: Anthropogenic climate change detected in European renewable freshwater resources, Nat. Clim. Change, 7, 813-816, https://doi.org/10.1038/nclimate3416, 2017.

Haddeland, I., Clark, D. B., Franssen, W., Ludwig, F., VOß, F., Arnell, N. W., Bertrand, N., Best, M., Folwell, S., Gerten, D., Gomes, S., Gosling, S. N., Hagemann, S., Hanasaki, N., Harding, R., Heinke, J., Kabat, P., Koirala, S., Oki, T., Polcher, J., Stacke, T., Viterbo, P., Weedon, G. P., and Yeh, P.: Multimodel estimate of the global terrestrial water balance: setup and first results, J. Hydrometeorol., 12, 869-884, https://doi.org/10.1175/2011JHM1324.1, 2011.
Hannaford, J., Buys, G., Stahl, K., and Tallaksen, L. M.: The influence of decadal-scale variability on trends in long European streamflow records, Hydrol. Earth Syst. Sci., 17, 2717-2733, https://doi.org/10.5194/hess-17-2717-2013, 2013.

Hannah, D. M., Demuth, S., van Lanen, H. A. J., Looser, U., Prudhomme, C., Rees, G., Stahl, K., and Tallaksen, L. M.: Large-scale river flow archives: importance, current status and future needs, Hydrol. Process., 25, 1191-1200, https://doi.org/10.1002/hyp.7794, 2011.

Hisdal, H., Stahl, K., Tallaksen, L. M., and Demuth, S.: Have streamflow droughts in Europe become more severe or frequent?, Int. J. Climatol., 21, 317-333, https://doi.org/10.1002/joc.619, 2001.

Hisdal, H., Holmqvist, E., Jónsdóttir, J., Jónsson, P., Järvet, A., Lindström, G., Kolcova, T., Kriauciuniene, J., Kuusisto, E., and Lizuma, L.: Climate change signals in streamflow data in the Nordic and Baltic region, edited by: Heinonen, M., Proceedings of the Third International Conference on Climate and Water, Helsinki, Finland, 182-187, 2007.

Hodgkins, G. A., Whitfield, P. H., Burn, D. H., Hannaford, J., Renard, B., Stahl, K., Fleig, A. K., Madsen, H., Mediero, L., Korhonen, J., Murphy, C., and Wilson, D.: Climatedriven variability in the occurrence of major floods across North America and Europe, J. Hydrol., 552, 704-717, https://doi.org/10.1016/j.jhydrol.2017.07.027, 2017.

Ilnicki, P., Farat, R., Górecki, K., and Lewandowski, P.: Impact of climatic change on river discharge in the driest region of Poland, Hydrolog. Sci. J., 59, 1117-1134, https://doi.org/10.1080/02626667.2013.831979, 2014.

Kendall, M. G.: Multivariate analysis, Griffin, London, 1975.

Khaliq, M. N., Ouarda, T. B. M. J., Gachon, P., Sushama, L., and St-Hilaire, A.: Identification of hydrological trends in the presence of serial and cross correlations: A review of selected methods and their application to annual flow regimes of Canadian rivers, J. Hydrol., 368, 117-130, https://doi.org/10.1016/j.jhydrol.2009.01.035, 2009.

Kulkarni, A. and von Storch, H.: Monte Carlo experiments on the effect of serial correlation on the Mann-Kendall test of trend, Meteorol. Z., 4, 82-85, 1995.

Kundzewicz, Z. W. and Robson, A. J.: Change detection in hydrological records: a review of the methodology, Hydrolog. Sci. J., 49, 7-19, https://doi.org/10.1623/hysj.49.1.7.53993, 2004.

Kundzewicz, Z. W., Graczyk, D., Maurer, T., Pińskwar, I., Radziejewski, M., Svensson, C., and Szwed, M.: Trend detection in river flow series: 1. Annual maximum flow, Hydrolog. Sci. J., 50, 5, https://doi.org/10.1623/hysj.2005.50.5.797, 2005.

Kundzewicz, Z. W., Merz, B., Vorogushyn, S., Hartmann, H., Duethmann, D., Wortmann, M., Huang, S., Su, B., Jiang, T., and Krysanova, V.: Analysis of changes in climate and river discharge with focus on seasonal runoff predictability in the Aksu River Basin, Environ. Earth Sci., 73, 501-516, 2015.

Kundzewicz, Z. W., Huang, J., Pinskwar, I., Su, B., Szwed, M., and Jiang, T.: Climate variability and floods in China - A review, Earth-Sci. Rev., 211, 103434, https://doi.org/10.1016/j.earscirev.2020.103434, 2020.

Laizé, C. L. R. and Hannah, D. M.: Modification of climate-river flow associations by basin properties, J. Hydrol., 389, 186-204, https://doi.org/10.1016/j.jhydrol.2010.05.048, 2010. 
Lehner, B., Döll, P., Alcamo, J., Henrichs, T., and Kaspar, F.: Estimating the impact of global change on flood and drought risks in Europe: a continental, integrated analysis, Climatic Change, 75, 273-299, 2006

Lobanova, A., Liersch, S., Nunes, J. P., Didovets, I., Stagl, J., Huang, S., Koch, del Rocío Rivas López, M., Fox Maule, C., Hattermann, F., and Krysanova, V.: Hydrological impacts of moderate and high-end climate change across European river basins, J. Hydrol.: Re. Stud., 18, 15-30, 2018.

Madsen, H., Lawrence, D., Lang, M., Martinkova, M., and Kjeldsen, T. R.: Review of trend analysis and climate change projections of extreme precipitation and floods in Europe, J. Hydrol., 519, 3634-3650, https://doi.org/10.1016/j.jhydrol.2014.11.003, 2014

Manabe, S., Wetherald, R. T., Milly, P. C. D., Delworth, T. L., and Stouffer, R. J.: Century-scale change in water availability: $\mathrm{CO}_{2}$-quadrupling experiment, Climatic Change, 64, 59-76, https://doi.org/10.1023/B:CLIM.0000024674.37725.ca, 2004.

Mann, H. B.: Nonparametric tests against trend, Econometrica, 13, 245-259, 1945

Mediero, L., Santillán, D., Garrote, L., and Granados, A.: Detection and attribution of trends in magnitude, frequency and timing of floods in Spain, J. Hydrol., 517, 1072-1088, https://doi.org/10.1016/j.jhydrol.2014.06.040, 2014.

Milliman, J. D., Farnsworth, K. L., Jones, P. D., Xu, K. H., and Smith, L. C.: Climatic and anthropogenic factors affecting river discharge to the global ocean, 1951-2000, Global Planet. Change, 62, 187-194, https://doi.org/10.1016/j.gloplacha.2008.03.001, 2008.

Milly, P. C. D., Dunne, K. A., and Vecchia, A. V.: Global pattern of trends in streamflow and water availability in a changing climate, Nature, 438, 347-350, https://doi.org/10.1038/nature04312, 2005.

Morice, C. P., Kennedy, J. J., Rayner, N. A., and Jones, P. D.: Quantifying uncertainties in global and regional temperature change using an ensemble of observational estimates: The HadCRUT4 data set, J. Geophys. Res., 117, D08101, https://doi.org/10.1029/2011JD017187, 2012.

Murphy, C., Harrigan, S., Hall, J., and Wilby, R. L.: Climatedriven trends in mean and high flows from a network of reference stations in Ireland, Hydrolog. Sci. J., 58, 755-772, https://doi.org/10.1080/02626667.2013.782407, 2013.

Orlowsky, B., Hoekstra, A. Y., Gudmundsson, L., and Seneviratne, S. I.: Today's virtual water consumption and trade under future water scarcity, Environ. Res. Lett., 9, 074007, https://doi.org/10.1088/1748-9326/9/7/074007, 2014.

Pandžić, K. and Trninić, D.: Principal component analysis of a river basin discharge and precipitation anomaly fields associated with the global circulation, J. Hydrol., 132, 343-360, https://doi.org/10.1016/0022-1694(92)90185-X, 1992.

Pellicciotti, F., Bauder, A., and Parola, M.: Effect of glaciers on streamflow trends in the Swiss Alps, Water Resour. Res., 46, 2009WR009039, https://doi.org/10.1029/2009WR009039, 2010.

Peña-Angulo, D., Nadal-Romero, E., González-Hidalgo, J. C., Albaladejo, J., Andreu, V., Bagarello, V., Barhi, H., Batalla, R. J., Bernal, S., Bienes, R., Campo, J., Campo-Bescós, M. A., Canatario-Duarte, A., Cantón, Y., Casali, J., Castillo, V., Cerdà, A., Cheggour, A., Cid, P., Cortesi, N., Desir, G., Díaz-Pereira,
E., Espigares, T., Estrany, J., Fernández-Raga, M., Ferreira, C. S. S., Ferro, V., Gallart, F., Giménez, R., Gimeno, E., Gómez, J. A., Gómez-Gutiérrez, A., Gómez-Macpherson, H., GonzálezPelayo, O., Hueso-González, P., Kairis, O., Karatzas, G. P., Klotz, S., Kosmas, C., Lana-Renault, N., Lasanta, T., Latron, J., Lázaro, R., Le Bissonnais, Y., Le Bouteiller, C., Licciardello, F., López-Tarazón, J. A., Lucía, A., Marín, C., Marqués, M. J., Martínez-Fernández, J., Martínez-Mena, M., Martínez-Murillo, J. F., Mateos, L., Mathys, N., Merino-Martín, L., Moreno-de las Heras, M., Moustakas, N., Nicolau, J. M., Novara, A., Pampalone, V., Raclot, D., Rodríguez-Blanco, M. L., RodrigoComino, J., Romero-Díaz, A., Roose, E., Rubio, J. L., RuizSinoga, J. D., Schnabel, S., Senciales-González, J. M., Simonneaux, V., Solé-Benet, A., Taguas, E. V., Taboada-Castro, M. M., Taboada-Castro, M. T., Todisco, F., Úbeda, X., Varouchakis, E. A., Vericat, D., Wittenberg, L., and Zabaleta, A., and Zorn, M. Spatial variability of the relationships of runoff and sediment yield with weather types throughout the Mediterranean basin, J. Hydrol., 571, 390-405, 2019.

Pettitt, A. N.: A non-parametric approach to the change-point problem, J. Roy. Stat. Soc. Ser. C, 28, 126-135, 1979.

Piniewski, M., Marcinkowski, P., and Kundzewicz, Z. W.: Trend detection in river flow indices in Poland, Acta Geophys., 66, 347 360, https://doi.org/10.1007/s11600-018-0116-3, 2018.

Renard, B., Lang, M., Bois, P., Dupeyrat, A., Mestre, O., Niel, H., Sauquet, E., Prudhomme, C., Parey, S., Paquet, E., Neppel, L., and Gailhard, J.: Regional methods for trend detection: Assessing field significance and regional consistency, Water Resour. Res., 44, W08419, https://doi.org/10.1029/2007WR006268, 2008.

Rogger, M., Agnoletti, M., Alaoui, A., Bathurst, J. C., Bodner, G., Borga, M., Chaplot, V., Gallart, F., Glatzel, G., Hall, J., Holden, J., Holko, L., Horn, R., Kiss, A., Kohnová, S., Leitinger, G., Lennartz, B., Parajka, J., Perdigão, R., Peth, S., Plavcová, L., Quinton, J. N., Robinson, M., Salinas, J. L., Santoro, A., Szolgay, J., Tron, S., van den Akker, J. J. H., Viglione, A., and Blöschl, G.: Land use change impacts on floods at the catchment scale: challenges and opportunities for future research, Water Resour. Res. 53, 5209-5219, https://doi.org/10.1002/2017WR020723, 2017.

Schmocker-Fackel, P. and Naef, F.: More frequent flooding? Changes in flood frequency in Switzerland since 1850, J. Hydrol., 381, 1-8, https://doi.org/10.1016/j.jhydrol.2009.09.022, 2010.

Sen, P. K.: Estimates of the regression coefficient based on Kendall's Tau, J. Am. Stat. Assoc., 63, 1379-1389, 1968.

Shorthouse, C. A. and Arnell, N. W.: Spatial and temporal variability in European river flows and the North Atlantic oscillation, in: FRIEND'97 - Regional Hydrology: Concepts and Models for Sustainable Water Resource Management, Proceedings of the Postojna Conference, September-October 1997, Slovenia, 77168, 1997.

Solomon, S., Manning, M., Marquis, M., and Qin, D.: Climate change 2007 - the physical science basis: Working group I contribution to the fourth assessment report of the IPCC, Cambridge University Press, Cambridge, 2007.

Sommer, C., Malz, P., Seehaus, T. C., Lippl, S., Zemp, M., and Braun, M. H.: Rapid glacier retreat and downwasting throughout the European Alps in the early 21st century, Nat. Commun., 11, 3209, https://doi.org/10.1038/s41467-020-16818-0, 2020. 
Spinoni, J., Naumann, G., Vogt, J., and Barbosa, P.: European drought climatologies and trends based on a multiindicator approach, Global Planet. Change, 127, 50-57, https://doi.org/10.1016/j.gloplacha.2015.01.012, 2015.

Stagge, J. H., Kingston, D. G., Tallaksen, L. M., and Hannah, D. M.: Observed drought indices show increasing divergence across Europe, Sci. Rep., 7, 14045, https://doi.org/10.1038/s41598-01714283-2, 2017.

Stahl, K., Hisdal, H., Hannaford, J., and Tallaksen, L.: Streamflow trends in Europe: evidence from a dataset of nearnatural catchments, Hydrol. Earth Syst. Sci., 14, 2367-2382, https://doi.org/10.5194/hess-14-2367-2010, 2010.

Steirou, E., Gerlitz, L., Apel, H., and Merz, B.: Links between large-scale circulation patterns and streamflow in Central Europe: A review, J. Hydrol., 549, 484-500, https://doi.org/10.1016/j.jhydrol.2017.04.003, 2017.

Teuling, A. J., Van Loon, A. F., Seneviratne, S. I., Lehner, I., Aubinet, M., Heinesch, B., Bernhofer, C., Grünwald, T., Prasse, H., and Spank, U.: Evapotranspiration amplifies European summer drought, Geophys. Res. Lett., 40, 2071-2075, https://doi.org/10.1002/grl.50495, 2013.

Teuling, A. J., de Badts, E. A. G., Jansen, F. A., Fuchs, R., Buitink, J., Hoek van Dijke, A. J., and Sterling, S. M.: Climate change, reforestation/afforestation, and urbanization impacts on evapotranspiration and streamflow in Europe, Hydrol. Earth Syst. Sci., 23, 3631-3652, https://doi.org/10.5194/hess-23-3631-2019, 2019.

Theil, H.: A rank-invariant method of linear and polynomial regression analysis, Koninklijke Nederlandse Akademie Van Wetenschappen, Amsterdam, the Netherlands, 16 pp., 1950.

Thober, S., Kumar, R., Wanders, N., Marx, A., Pan, M., Rakovec, O., Samaniego, L., Sheffield, J., Wood, E. F., and Zink, M.: Multi-model ensemble projections of European river floods and high flows at 1.5, 2, and 3 degrees global warming, Environ. Res. Lett., 13, 014003, https://doi.org/10.1088/17489326/aa9e35, 2018.

Urbonas, B. and Stahre, P.: Stormwater: Best management practices and detention for water quality, drainage, and CSO management, available at: http://worldcat.org/isbn/0138474923 (last access: 22 October 2021), 1993.
Vicente-Serrano, S. M., Lopez-Moreno, J.-I., Beguería, S., Lorenzo-Lacruz, J., Sanchez-Lorenzo, A., García-Ruiz, J. M., Azorin-Molina, C., Morán-Tejeda, E., Revuelto, J., Trigo, R., Coelho, F., and Espejo, F.: Evidence of increasing drought severity caused by temperature rise in southern Europe, Environ. Res. Lett., 9, 044001, https://doi.org/10.1088/1748-9326/9/4/044001, 2014.

Viglione, A., Borga, M., Balabanis, P., and Blöschl, G.: Barriers to the exchange of hydrometeorological data in Europe: Results from a survey and implications for data policy, J. Hydrol., 394, 63-77, https://doi.org/10.1016/j.jhydrol.2010.03.023, 2010.

Von Neumann, J.: Distribution of the ratio of the mean square successive difference to the variance, Ann. Math. Stat., 12, 367-395, 1941.

von Storch, H.: Misuses of statistical analysis in climate research, in: Analysis of climate variability - Applications of statistical techniques, Springer Verlag, 334 pp., 1995.

Willems, P.: Multidecadal oscillatory behaviour of rainfall extremes in Europe, Climatic Change, 120, 931-944, https://doi.org/10.1007/s10584-013-0837-x, 2013.

Yue, S. and Pilon, P.: A comparison of the power of the $t$ test, MannKendall and bootstrap tests for trend detection, Hydrolog. Sci. J., 49, 21-37, https://doi.org/10.1623/hysj.49.1.21.53996, 2004.

Yue, S. and Wang, C.: The Mann-Kendall test modified by effective sample size to detect trend in serially correlated hydrological series, Water Resour. Manage., 18, 201-218, https://doi.org/10.1023/B:WARM.0000043140.61082.60, 2004.

Yue, S., Pilon, P., and Phinney, B.: Canadian streamflow trend detection: impacts of serial and cross-correlation, Hydrolog. Sci. J., 48, 51-63, https://doi.org/10.1623/hysj.48.1.51.43478, 2003.

Zeng, Z., Piao, S., Lin, X., Yin, G., Peng, S., Ciais, P., and Myneni, R. B.: Global evapotranspiration over the past three decades: estimation based on the water balance equation combined with empirical models, Environ. Res. Lett., 7, 014026 , https://doi.org/10.1088/1748-9326/7/1/014026, 2012. 